\title{
FUNGSI MASJID DALAM MASYARAKAT PERALIHAN
}

\author{
Imam MusGmin \\ Fakultas Humaniora dan Budaya, Universitas Islam Negen (UIN) Malang, \\ Gedung IImu-IImu Sosial It.1, Jl. Gajayana 50 Malang 65144 \\ Telp. 0341-551354, 558882 Faks. 0341-572533, 0341-558882.
}

\begin{abstract}
This Study is an effort to comprehend mosque by treating micro approach at specific society, that is transiting society. In Selecting mosque used as a research object, the researcher have treated micro sociology approach at restricted research are and specifically to the transiting society. In society, mosque have been experienced to many transitional function and value friction. For nowadays, mosque is just like a bus station. We come on it, we take a pray and sit down for a while then go out without any conversation even less recognizing the persons sitting beside us. Such reality needs a serious concern from the religionist in under that could be well formulated back to the function of mosque properly. As a matter of fact, those efforts have been done many mites, however it didn't show any applied formulations. There for, it needs certain applied formulations toward mosque functions interely. With some varieties, the transiting society have been shown enthusiasm where the mosque roles existing in many activities both education field, politics social and culture. This enthusiasm needs support from any sides in order that they would not fall down into opposite norms.
\end{abstract}

Key quords: mosque, transiting society

Ulul Albab, Vol. 8 No. 2, 2007 


\section{Pendahuluan}

Beberapa studi tentang masjid sampai pada suatu pemahaman bahwa masjid merupakan simbol yang penting bagi persatuan dan kesatuan umat Islam. Bahkan masjid menjadi pusat kegiatan umat Islam hamper di segala bidang. Pengajaran agama Islamdan penyebarannya pun dimulai dari masjid. Sewaktu Rasulullah Muhammad SAW pindah (hijrah) dari Makkah ke Yasrif, pertama-tama yang dibangun adalah masjid yang selanjutnya dijadikan pusat segala kegiatan bagi umat Islam.

Gazalba, dalam sebuah karyanya menyoroti tentang masjid sebagai pusat kebudayaan dalam pengertian yang sangat luas tidak hanya untuk beribadah (kegiatan ritual) saja. Gazalba memformulasikan pemikiran bahwa masjid mempunyai peranan yang sangat penting pada tataran normatif dan historis secara luas. Namun pada tataran praktis Gazalba tidak banyak menganalisa data posisi masjid dalam hubungannya dengan perubahan dan gerak masyarakat secara lengkap seperti ketika mengupas pada tataran normatif dan historis(Gazalba, 1994:196)

Abubakar Aceh, seperti halnya Gazalba mengupas secara lengkap masjid dalam tataran normatif dan historis yang membawa pada satu kesimpulan akan pentingnya kedudukan masjid bagi masyarakat Islam. Pertama, pola yang yang digunakan melalui pendekatan historis yang membahas dan membuktikan akan kedudukan masjid, bagaimana nabi dan para sahabat memfungsikan masjid. Kedua, melalui pendekatan normatif yaitu membuktikan secara doktrin masjid mempunyai posisi yang sangat penting.

Pada tataran ini Aceh merasa berkepentingan untuk membahas hukum-hukum Islam mengenai masjid dan secara spesifik menampilkan pemikiran Imam Syafi'i. Sehingga dapat dikatakan baik Gazalba maupun Aceh sama-sama memposisikan masjid secara ideal dan tentunya melakukan kritik kepada masjid yang kurang berhasil meneruskan apa yang dilakukan oleh Nabi Muhammad(Aceh, 1959:427).

Kedua studi di atas masih menggunakan analisa yang bersifat makro, bukan pada gambaran yang bersifat mikro sehingga hasilnya menggambarkan 
masjid secara global yang belum sepenuhnya sepesifik. Bahkan analisa yang digunakan bukan hasil dari pemikiran sosiologis, tidak mempresentasikan pemahaman sosiologis dalam memposisikan masjid di tengah-tengah masyarakat yang terus mengalami perubahan. Misalnya belum menentukan kriteria yang jelas dan spesifik tentang gerak yang terjadi di masyarakat, baik itu gerak mobilitas ekonomi, sosial dan pengaruhnya terhadap masjid.

Demikian juga studi-studi tentang masjid seringkali bersifat analisa arsitektur dan tidak menganalisa demensi perubahan sosial pada masyarakat masjid tersebut . Studi yang dilakukan oleh Syarwandi(Syarwandi, 1995:49), misalnya menganalisa dari berbagai segi masjid Kudus. Pada pemahaman arsitektur, Syarwandi telah melakukan studi yang sudah terspesifikasi (masjid Kudus).

Pemilihan studi serupa, juga dilakukan oleh penulis buku lainnya yang memilih menganalisa masjid sebagai sebuah bangunan yang mempunyai nilai arsitektur tinggi, seperti yang dilakukan oleh Amir Husein, yang banyak menulis tentang kebudayaan Islam yang secara istimewa membahasa "Ilmu Bangunan dan Teknologi" menempatkan masjid sebagai produk yang bernilai historis dan seni yang tinggi. Suatu kesimpulan yang sudah dapat diduga sebelumnya adalah bahwa umat Islam telah mampu menciptakan suatu seni arsitektur yang bermutu (Amir, 1979:177).

Syarwandi dan Husain telah melakukan studi secara spesifik terhadap setiap sudut karya seni arsitekturnya dengan pendekatan keilmuan yang memadai. Penelitian terhadap masjid dan kaitannya dengan gerak perubahan di masyarakatnya perlu diteliti secara spesifik dengan melihat setiap sudut yang akan mempengaruhi praktek masjid sebagai sentral kegiatan umat Islam. Sama halnya seperti seorang arsitektur yang menganalisa setiap detail bangunan secara terperinci, gejala sosial dan kaitannya dengan masjid perlu diteliti kembali.

Kalau diperhatikan antara gejolak sosial yang paling terlihat di Indonesia adalahmasyarakat peralihan (pra Industri). Di mana masyarakat ini mulai meninggalkan kebiasaan agraris menuju industri, dari pedesaan menuju tipe perkotaan. Di masa inilah menupakan kondisi yang serba rawan, 
perubahan terjadi secara cepat dan menjadi faktor determinan dalam kehidupan masyarakat.

Dengan dasar pemikiran seperti tersebut di atas penulis berkeinginan dan menyadari perlu diadakan studi terhadap masjid dengan pendekatan yang bersifat mikro dalam pemilihan masyarakat yang jelas dan spesifik. Dan yang terpenting lagi adalah menentukan gerak dinamika masyarakat mempengaruhi atau tidak terhadap masjid.

Studi ini sebagai usaha memahami Masjid dengan pendekatan mikro pada masyarakat yang sepesifik, sehingga akan dapat diketahui karakteristik dan proses adaptasi masyarakat terhadap perubahan yang sedang terjadi.

Di samping dasar latar belakang di atas penulis juga menyadari betapa pentingnya studi-studi terhadap perubahan di masyarakat dikaitkan dengan peranan masjid dalam berbagai bidang dari ibadah ritual hingga bidang politik. Maka studi terhadap masjid harus dikaitkan dengan perubahan yang terjadi di masyarakat.

Berdasarkan lawar belakang diatas penelitian ini memilih masjid sebagai obyek dengan menggunakan sosiologi yang bersifat mikro, dengan memilih area penelitian yang terbatas secara spesifik pada masyarakat peralihan. Hal ini menarik diteliti karena belum banyak studi terhadap masjid dengan pendekatan mikto yang ditunjang dengan kembali digairahkannya kegiatan.kegiatan masjid di masyarakat secara luas.

\section{Rumusan Masalah}

Berangkat dari latar belakang di atas yang maka yang menjadi menjadi pokok permasalahan dalam penelitian ini adalah:

1. Bagaimana pandangan masyarakat peralihan terhadap fungsi masjid?

2. Varian manakah yang paling banyak memfungsikan masjid? 


\section{Tujuan dan Kegunaan Penelitian}

Penelitian ini bertujuan untuk mempelajari hubungan antara perubahan sosial serta berbagai aspeknya di masyarakat peralihan yang berhubungan dengan pemanfatan masjid. Sesuai dengan rumusan masalah, tujuan penelitian ini adalah:

1. Untuk mengetahui pandangan masyarakat peralihan tentang fungsi masjid.

2. Untuk mengetahui varian yang paling banyak memfungsikan masjid.

Melanjutkan tujuan di atas maka penelitian ini diharapkan dapat berguna dan dapat memberikan sumbangan baik bersifat teoritis maupun operasional. Secara teoritis dari hasil penelitian ini dapat memberikan tambahan khazanahilmu pengetahuan dalam berbagai pemahaman terutama mengenai fungsi masjid, akibat adanya erus perubahan sosial budaya yang ada pada masyarakat. Sedangkan secara operasional dapat dijadikan sebagai pedoman di dalam upaya memajukan dan mengembangkan fungsi masjid di tengah-tengah masyakat.

\section{Kajian Teoritis}

Dalam pendahuluan telah dibicarakan bahwa masjid berfungsi sebagai sentral kegiatan umat Islam. Untuk memberikan gambaran yang lebih jelas perlu diperinci peran tersebut, yang diperinci berdasarkan praktek penting yang dilakukan di dalam masjid, antara lain

1. Masjid Sebagai Tempat Pendidikan

Pendidikan di sini tidak hanya ilmu-ilmu agama saja akan tetapi juga ilmu-ilmu yang lain yang dianggap penting di masyarakat. Bahkan Nabi Saw biasa mengadakan ta'lim (pengajaran) dengan membentuk lingkaran (halaqat) yang merupakan komunitas orang-orang belajar tentang ilmu agama dan kemasyarakatan. Banyak hadits-hadtis Nabi 
Saw yang menceritakan akan hal ini. Seperti diceritakan oleh sahabat Anas bin Malik pembantu (khadam) nabi yang sangat setia kepada beliau. Pada suatu hari kami duduk bersama dengan para sahabat yang lain di majlis (halaqat) Rasulullah SAW. Ketika itu ia bersabda:"Jangan duduk bersama saya (dekat saya) hari ini orang yang memutuskan tali persaudaraannya. Mendengar sabda beliau yang demikian itu bangkitlah seorang pemuda seraya meninggalkan masjid Rasulullah SAW. Rupanya pemuda ini sudah beberapa hari tidak bertegursapa dengan bibinya, sudah beberapa waktu ia meninggalkan bibinya, lalu pemuda tersebut mendatangi bibinya lantas meminta maaf kepadanya keduanya saling memberi maaf. Setelah kejadian itu, pemuda tersebutkembali mengikuti ta'lim di majlis Rasul yang mulia ini. Kemudian Rasul bersabda: "Sesungguhnya rahmat Allah tidak akan diturunkan kepada suatu kelompok kaum yang di dalamnya ada orang yang saling tidak menyapa (memutuskan tali persaudaraan (Rahmat, 1992:47). Dari keterangan hadits tersebut di atas dapat dipahami bahwa Nabi dalam proses pendidikan untuk menamkan nilai-nilai keislaman sering membentuk lingkaran (halaqat) yang dilakukan di dalam masjid. Masjid pada awalnya benar-benar menajadi tempat tunggal belajar ilmu agama, namun dalam perkembangannya muncul sistem baru yang dikenal dengan Madrasah atauSekolah.Menurut Syekh Husain Nast, bahwa madrasah merupakan kelanjutan dari perkembangan belajar yang sudah dirintis dari masjid, secara geografikal madrasah tidak bisa dipisahkan dengan masjid. Karena sejak awal nabi mengajar al Qur'an dan Sunnah di masjid dan hal ini dilanjutkan oleh para sahabat bahkan sampai tabi'in.

Gambaran yang lebih rinci tentang hal tersebut dijelaskan oleh Gazalba dengan mengutip pendapat Ahmed MA, sebagai berikut: "Masjid bertindak sebagai pusat-pusat pendidikan dan merupakan tempattempat untuk kuliah-kuliah tentang Hadits dan al Qur'an. Ahli ilmu Maqdisi berkeliling melalui Syuriah, Palestina, Mesir dan Persia telah memilih masjid sebagai tempat kegiatan intelektualisme dan tempat pendidikan mereka. Imam Syafi'I memberikan pendidikannya di masjid 
al Amr di Fustat sampai meninggal tahun 920 A.C. Ibnu Hauqal di Siyistam. Bukan saja pendidikan agama, tetapi juga mata-mata pelajaran bahasa, filsafat dan kesusasteraan diajarkan di masjid-masjid berlangsung sampai abad II A.C. adalah bebas bayar bagi semua Muslim. H.M. Yunan Nasution dalam Ahmad Fatah Yasin, menulis bahwa masjid sebagai lembaga pendidikan Islam (da'wah) terutama di kampus-kampus paling tidak ada 3 sasaran implikatif yang perlu dijadikan prioritas dalam mengembangkan kualitas manusia (mahasiswa), yaitu; 1) meningkatkan dasar-dasar pengetahuan mahasiswa tentang pokok ajaran Islam, sehingga mereka menyadari dan menghayati kelengkapan Islam sebagai Way of life. 2) melatih atau mentradisikan mahasiswa untuk melakukan kegiatan ritual mumi berdasarkan al Qur'an dan SunnahNabi, sehingga mereka selalu komunikatif dengan Tuhan, yang akhirnya terbentuk suatu kemandirian, optimis, berprediksi dan sebagainya. 3) mendidik mahasiswa untuk peka dan merasa terpanggil terhadap persoalan kehidupan sosial, melaksanakan amar ma'nuf nahi muankar, serta menyatu dengan kehidupan umat manusia (Yasin, 1999:73). Dengan demikian sangatlah wajar jika tumbuh dan berkembang ilmu pengetahuan hampir di segala bidang dan tidak terjadi dikotomi antara ilmu agama dan ilmu non agama, semuanya diajarkan melalui masjid. Bahkan menurut Nurcholish (1989:131: 1995:160, masjid adalah salah satu sebab yang menjadikan umat Islam begitu bersemangat untuk belajar ilmu pengetahuan adalah adanya doktrin yang mengharuskan (wajib) bagi umat Islam untuk belajar dalam sekala yang lebih luas tidak terikat oleh nation atau suku bangsa. Dengan demikian maka wajar saja jika kemudian umat Islam mampu meninggalkan orang Yunani jauh di belakang. Perkembangan ilmu pengetahuan dalam masyarakat Islam tidak bisa dipisahkan dari doktrin Islam yang memang menganjurkan mengembangkan ilmu pengetahuan dan memberikan penghormatan kepada yang berilmu. Banyak ayat al Qur'an maupun sunnah yang menegaskan terhadap hal ini, bahwa orang yang berilmu akan mendapat derajat tinggi dihadapan Tuhannya, belajar atau mencari ilmu adalah 
aktifitas yang paling mulia dalam Islam, karena dengan ilmu orang Islam akan mengetahui kesalahan dan kebenaran keyakinannya dan dengan ilmu pula ia akan bisa berbuat dengan benar (Al Qari, 1990:15). Kelebihan orang berilmu dari seorang ahli ibadah bagaikan kelebihanku terhadap orang rendah dintara kamu. Kemudian Nabi bersabda; "Sesungguhnya Allah dan para malaikat-Nya, semua yang tinggal di langit dan bumi hingga binatang semut yang ada dilobangnya serta ikan-ikan yang ada di lautan semuanya selalu mendo'akan kepada para pendidik yang mengajarkan al khair (al Nawawi (Al Nawawi, 1987:353). Berdasarkan doktrin seperti telah diuraikan di atas dapat dikatakan bahwa umat telah membuktikan dalam sejarah perkemabangan ilmu pengetahuan yang sedemikian pesatnya sehingga mampu menjadi pusat peradaban dunia, dan semunya itu di mulai dari masjid.

2. Masjid Sebagai Tempat Aktifitas Politik Pengertian politik di sini seperti yang diungkapkan oleh Robert A. Dahl, yaitu ...... as any persistent pattern of human relationship that involves to sing extent, power or auchority (Kartoprawiro, 1986:77). Sedangkan praktek politik mengacu kepada pengertian yang dibuat oleh Christhoper Loyd, bahwa praktek politik sebagai tindakkan yang diajukan untuk menggunakan dan mempengaruhi kekuasaan (Cristhoper, 1987:3). Dalam sejarah terutama masa awal Islam tidak ada pemisahan antara kepentingan politik negara dan agama. Sebagai pemimpin, Nabi dan para penggantinya (khalifah) adalah Imam-imam agama (Gazalba:193). Masjid Quba pada masa Nabi menjadi sentral pergerakan Islam, Nabi memainkan peran politik untuk -mempengaruhi kebiasaan masyarakat seperti dengan adanya perjanjian Madinah (mitsaq al madinah) yang terkenal dikalangan kita dengan sebutan Piagam Madinah. Nabi memusatkan pelayanan umat di dalam masjid sehingga masyarakat akan meninggalkan pola berfikir rasisme dan sikap sektarian. Nabi menciptakan stabilitas dari perbedaan suku yang ada, dengan membangun suatu kerangka dasar seperti: Mempertahankan kesatuan dan kelangsungan hidup, dan kelompok 
melalui kerja sama yang baik. Mendidik dan menanamkan dalam diri bawahan rasa tanggungjawab. Menyadarkan anggotanya bahwa kepentingan dari kelompok tidak terlepas dari realisasi tujuan obyektif individu. Segala kebijakan Nabi di bidang kemasyarakatan merupakan "Praktek Politik" yang mendukung program-program lainnya sebagai efek dari terciptanya kondisi masyarakat baru. Gazalba menyebutnya sebagai: "Politik Islam adalah pembentukkan kekuasaan untuk mengatur sosial dan ekonomi menurut keyakinan, jadi bukan menurut ideologi, anggapan atau kepercayaan. Keyakinan itu adalah al Qur'an dan Hadits.Berdasarkan pada keyakinan baru sebagaimana dalam bahasa Hegel " Negara sebagai cita-cita moral" (Ralf Dahrendrof dalam Christoper Loyd, mulai terlihat dibangun oleh Nabi. Moral yang disepakati adalah moral yang ada dalam al Qur'an dan Sunnah Nabi. Persekutuan masyarakat yang didasarkan pada kesamaan visi dan sudut pandang terhadap moralitas, bukan suatu tatanan masyarakat yang berdasarkan pada kesamaan suku, kesamaan ras ataupun persekutuan lewat paksaan kekuasaan (militer).Masjid memerankan sebagai simbol titik temu dari berbagai perbedaan yang ada. Kondisi seperti ini mendorong akan munculnya perkembangan (progress) pada bidangbidang yang lain sebagai dampak kesamaan visi terhadap tujuan praktek politik untuk masyarakat baru.

3. Masjid Sebagai Tempat Praktek Sosial Praktek sosial di sini mencakup hubungan dengan sekitarnya baik itu dalam kapasitas individu ataupun kelompok. Nurcholish berpendapat bahwa dari hal yang teologis sifatnya akan berkembang menjadi praktek sosial seperti dalam shulat. Sholat, menurutnya adalah menghadap Allah dan berkomunikasi dengan Dia. Baik melalui bacaan, maupun melalui tingkah laku (khusunya ruku' dan sujud). Dan disebut sholat bermakna instrumental, karena ia di pandang sebagai sarat untuk mencapai sesuatu di luar dirinya.

Ulul Albab, Vol. 8 No. 2, 2007 
Dalam Islam hampir tidak didapatkan suatu ibadah (ritual) yang tidak mempunyai makna implikasi sosial. Dengan ungkapan yang sederhana, misalnya dapat dirumuskan: "Orang yang berketuhan Yang Maha Esa, harus berperikemanusiaan yang adil dan beradap"(meminjam istilah yang ada dalam Dasar Negara Republik Indonesia yaitu Pancasila). Kita mengambil contoh, misalnya sholat yang merupakan tiang agama, dalam arti orang yang meninggalkan sholat ibarat orang tersebut telah merobohkan tiang bangunan agama itu sendiri. Ia dimulai dengan takbir, takbir permulaan ini disebut oleh para ahli hukum Islam (fuqaha) takbir al ihram, yang apabila kita menggunakan pendekatan semantik dari pengertian takbir al ihram ini adalah sebagai berikut: Ia berasal dari dua kata yang durangkai, yaitu takbir (membesarkan) dan ihram (mengharamkan, melarang dsb). Sehingga bisa mengambil pengertian jika seseorang sudah dimulai shalatnya yang dimulai dengan takbir al ihram, maka ia diharamkan untuk melakukan apa saja yang tidak ada hubungannya dengan sholat, misalnya menulis, membikin kontrak kerja dan sebagainya. Kenapa dilarang? Karena kita sudah menyatakan diri untuk berkomunikasi dengan Yang Maha Segalanya. Walhasil pekerjaan yang berdemensi horizotal sama sekali tidak diperkenankan (diharamkan) untuk dilakukan di dalam sholat. Akan tetapi walaupun demikian, sholat harus diakhiri dengan ucapan salam (assalamu alaikum warahmarullah wabarakatuh). Yang mempunyai pengertian bahwa kita wajib menciptakan suasana aman, selamat, kasih dan barakah. Demikian juga ibadah-ibadah (ritual) yang lainnya. Di dalam Islam peribadatan merupakan awal memahami lingkungan dan sitem sosial yang ada. Dengan demikian fungsi sosial masjid adalah bagian yang tidak terpisahkan dengan fungsi peribadatannya. Salah satu yang terpenting adalah melanjutkan equilibrum masyarakat yang telah dicapai dalam bidang politik dengan mengurangi (bahkan menghilangkan) "dysfunction" dalam masyarakat. (Dysfunction di sini berarti "setiap item atau social usage yang membantu kehancuran sistemsosial) (Poloma, 1986:424). Dengan memberikan hukuman bagi mereka yang melanggar dari cita-citra moral Islam. Untuk melindungi sistem sosial yang ada Islam mempunyai 
perundang-undangan yang jelas di bidang pidana (jinayat) dan perdata (muamalat).

\section{Metodologi}

\section{Pendekatan Penelitian}

Penelitian ini memusatkan perhatian pada fungsi majid di kalangan Santri, Abangan dan Telukkan, maka digunakan studi fenomenologi. Sebagai penelitian yang menerapkan pendekatan studi fenomenologis sekaligus pendekatan kualitatif, maka ciri-ciri atau karakter penelitian kualitatif selalu diperhatikan. Ciri-ciri atau karakter dimaksud menurut Bogdan dan Biklen (Nasution, 1998:27) diantaranya: 1) Mempunyai latar alami (the natural setting) sebagai sumber data langsung dan peneliti menjadi instrumen kunci (the key instrument), 2) Bersifat deskriptif, yang menggambarkan situasi tertentu dan pandangan tentang dunia secara deskriptif, 3) Lebih mementingkan proses daripada hasil semata, 4) Cenderung menganalisis data secara induktif dan 5) Makna merupakan hal yang esensial.

Sesuai pandangan Bogdan dan Biklen, setting penelitian ini adalah situasi kondisi dan peristiwa yang terjadi di beberapa masjid di Desa Candi, dimana peneliti berada disetting penelitian dengan mengamati fenomena dan pengumpulan data langsung, sehingga dapatmemahami, mengerti serta memberi makna dari peristiwa yang terjadi pada subjek yang diteliti serta dapat menggambarkan dan mengkaji secara langsung hubungan-hubungan fenomena yang terjadi. Dalam proses penelitian berarti proses menduduki peranan penting dalam menentukan hasil penelitian. Berbagai fenomena ditelaah secara luas untuk selanjutnya dihubungkan antara fenomena yang satu dengan lainnya, sehingga mengkristal menjadi bagian atau sub-sub bagian yang menuju kepada kecendrungan khusus dan akhirnya dapat diberikan makna dari berbagai fenomena tadi.

Obyek penelitian adalah masyarakat peralihan (Santri, Abangan dan Telukkan). Dengan obyek tersebut, maka populasitersebut sekaligus subyek penelitian adalah masyarakat Desa Candi Kotamadya Malang. 
Dalam rangka memadai pelaksanaan penelitian ini digunakan model desain yang ditawarkan Bogdan dan Biklen yang disajikan dalam bentuk funnel (cerebong). Model ini melukiskan proses penelitian yang berawal dari ekplorasi yang luas, berlanjutnya dengan pengumpulan dan analisa data yang lebih terarah menyempit dan mendalam, sehingga diperoleh kesimpulan mengenai pandangan dan pendapat masyarakat peralihan tentang fungsi masjid di Desa Candi.

\section{Sumber dan Teknik Pengumpulan Data}

Sebagaimana diungkapkan Lofland, sumber utama dalam penelitian kualitatif adalah kata-kata dalam tindakan, selebihnya adalah data-data tambahan seperti dokumen dan sebagainya. Selaras pendapat tersebut, maka data-data berupa kata-kata atau tindakan mengenai dampak indtrialisasi terhadap pola konsumsi masyarakat desa menjadi data utama penelitian. Data tersebut digali melalui responden dan informan. Masyarakat sebagai subyek penelitian diberlakukan sebagai responden penelitian. Sedangkan informan penelitian adalah dari berbagai pihak.

Pengumpulan data dilakukan secara sirkulasi dengan menggunakan tiga pendekatan yaitu: 1) Wawancara konprehensif (indepth interviewing), 2) Pengamanan peran serta (participant obseravation), dan 3) Dokumentasi. Metode pengumpulan data ini pada dasarnya dikelompokkan menjadi dua cara yaitu : 1) Metode interaktif yang meliputi wawancara dan observasi serta, 2) Metode non interaktif seperti dokumenta. Ketiga metode atau teknik tersebut dilakukan secara berulang-ulang sesuai dengan pertanyaan atau keperluan yang muncul pada saat tertentu.

Teknik wawancara yang digunakan sebagaimana yang telah diperaktikkan Dananjaya, yaitu wawancara tak berstruktur (unstruktur interview) dengan dua bentuk yaitu wawancara terarah (di rected) yang disebut juga wawancara berpokus tidak terarah (non directed) yang disebut juga wawancara bebas (free interview).

Wawancara mendalam dilakukan dengan masyarakat Desa Candi yang dipandang layak dijadikan informan kunci dalam menggambarkan fenomena 
yang diteliti. Sedangkan pengamatan berperanserta, peneliti lekukang dengan mengamatisecara langsung berbagai tindakan masyarakat peralihan. Dengan mengamati hal-hal tersebut diperoleh data obyektif mengenai fungsi masjid. Sedangkan metode amgket dipergunakan untuk memperoleh data tentang prosentase keterlibatan responden terhadap pemaknaan fungsi masjid, metode ini sebagai penguat terhadap hasil wawancara dan observasi. Sementara itu metode dokumenter dalam penelitian ini diberlakukan sebagai metode penunjang, terutama untuk menggali data tentang gambaran umum Desa Candi.

Teknik analisa data yang digunakan dalam penelitian ini adalah kualitatif deskriftif untuk menjawab permasalahan penelitian yang telah dirumuskan sebelumnya. Proses analisa data naturalistik dalam peraktik tidaklah dapatlah dipisah-pisahkan dengan proses pengumpulan data. Kedua kegiatan ini berjalan serempak, artinya analisa data dikerjakan bersamaan dengan pengumpulan data dan dilanjutkan setelah pengumpulan data selesai.

Miles dan Hoberman, menyarankan analisis dilakukan dengan menggunakan tiga alur yaitu 1) Reduksi data, 2) Penyajian data dan 3) Penarikan kesimpulan / verifikasi.

\section{Hasil Penelitian}

Masjid memerankan posisi strategis bagi umat Islam dalam batas-batas yang berbeda. Perbedaan tersebut dikarenakan adanya varian yang berbeda dalam masyarakat. Varian Santri yang dianggap paling banyak mengambil fungsi masjid dalam berbagai aktifitas, baik pendidikan, politik, sosial maupun budaya tidak sepenuhnya benar. Dalam penelitian terlihat_pada bidangtertentu varian Santri masih di bawah yang yang lain. Seperti di badang pendidikan, varian Telukkan lebih menunjukkan tingkat belajar yang lebih tinggi dibanding dengan varian Santri maupun Abangan. Hal ini dikarenakan vairian Telukkan merasa bahwa belajar, khususnya ilmu agama merupakan kunci keselamatan hidup setelah mati. Mereka meyakini bahwa satu-satunya bekal untuk selamat dari siksa neraka adalah dengan 
mendalami ilmu agama. Varian Telukan ini rata-rata berpendapat bahwa hidup mereka tidak lama lagi dan mereka menarauh perhatian pada belajar agama yang dianggap menjadi penyelamat terhadap dirinya kelak.

Sedangkan praktek politik, varian Santri menunjukan minat yang cukup tinggi terhadap penggunaan masjid sebagai simbol dalam perjuangan membentuk Islam yang mereka anggap lebih mampu mewakili varian mereka. Di bidang politik makro maupun mikro tercipta konflik dan persaingan antar varian Santri yang menggunakan simbol Islam, dengan varian Abangan yang menggunakan simbol nasionalis. Pada posisi persaingan antar varian Santri dan Abangan terjadi tarik manarik untuk merebutkan varian Telukan.

Pada praktek budaya terjadi proses pembaharuan antara varian yang ada, di mana simbol-simbol yang biasanya milik varian Santri sudah mulai terbiasa dilakukan oleh varian yang dahulu berasal dari vaian Abangan dan Telukan. Sehingga menghasilkan varian Santri baru yang bersal dari Abangan.

\section{Kesimpulan} berikut:

Dari penelitian yang dilakukan dapat dipaparkan secara singkat sebagai

1. Bahwa dari berbagai varian keagamaan yang ada telah menunjukan semangat mereka masing-masing terhadap masjid dalam berbagai praktek yang ada, baik pendidikan, politik, sosial maupun budaya.

2. Varian Telukkan sebagai orang yang bisa dikatakan telah masuk menjadi Santri karena mereka telah mau menjalankan agama akan tetapi dalam hal-hal tertentu perlu mendapat pengawasan. Sebab kadang-kadang sikap mereka yang asli muncul, apakah mereka yang berasal dari PKI atau yang lainnya.

3. Pada varian Abangan terdapat sikap yang lebih toleran terhadap ajaran agama yang baru. 
4. Sedangkan Varian Santri mulai terjadi pergeseran sikap, yaitu dari sikap cemburu terhadap ajaran yang tidak sesuai dengan keyakinan mereka, pada beberapa kasus keagamaan mereka mulai bisa menerima sekalipun berbeda dengan ajaran agama yang mereka anut sebelumnya.

\section{DAFTAR PUSTAKA}

Aceh, Abubakar, Sejarah Masjid dan Amal Ibadah di Dalamnya, CV Adil, Banjarmasin 1959.

Ahmad Fedyani Saifudien, Konflik dan Integrasi: Perbedaan Faham Dalam Ajaran Islam, Rajawali Press Jakarta 1986.

Al Buthy, Muhammad Sa'id Ramdhan, Figh al Sirah: Dirasat Monhajizyat Ilmiyar li sirah al Musthafa Saw, Dar al fikr Beirut 1980

Al Faruqi, Ismail Raji. Tauhid, terj. Pustaka Pelajar Yogyakarta 1992.

Al Ghozali, Syeh Imam, Studi Kritis Atas Hadis, Antara Tekstual dan Kontekstual, Mizan Bandung, 1994.

Al Husainy, al Maqdisy, Fath al Rahman Li Thalib Ayat al Qur'an, Dar al Fikr Beirut tanpa tahun.

Al Razy, Muhammad Abi Bakr, Tafsir al Razy : Unmudaj Jalil Fi Asilah wa Ajwibah Min Gahara'ib al Tanxil, Dar al Fikr Beikrut 1990

Ali, Abdullah Yusuf, The Holy Qur'an, Dar al Fikr Beirut 1978

Ary, D.J.I.C, 1985, An Introduction to Research, New York, Halt Rinehert and Winston.

Ashim, Abdul Aziz Fattah al Qari', Bamamÿ Amaly Lial Mutafaqihin: Tsaman Dhanuriyat Li Kulli Man Yastaghil Bi Thalab al Ilm Wa al Tafaqquh Fidinillah, Maktabah al Shadiq Thaif 1990

Audah, Ali. Konkordansi al Qur'an, Lintera Antarnusa, Jakarta, 1995.

Baali, Fuad, Society State and Utomiom: Ibn Kholdren's Sosiologi Thought, State university New York 1988

BMPTSI (Badan Musyawarah Perguruan Tinggi Suwasta Indonesia), Wilayah VII, Jawa Timur, 1989, Pelatihan Metode Penelitian Kualitatif, (Kumpulan Materi), Surabaya.

Bogdan RC, dan Biklen SK, 1982, Qualitative Research for Education and Introduction to Theory and Method, Allyn and Brem, London. 
Calvin, Goldscheider, 1985, A, Introduction to Research, New York, Halt Rinehart and Winston.Cliford Gertz, Perubahan Sosial dan Modemisasi di dua Kota di Indonesia, dalam Taufik Abdullah, Agama Ethos Kerja dan Perkembangan

Haikal, M. Husain, Sejarah Hidup Muhammad, Terj. Lintera Anta Nudsa Jakarta 1989.

Halim, Nur FA., Upaya Pembinaan. Dan Pengembangan Pendidikan Agama Islam Dalam Menghadapi Kemerosotan Moral, IAIN Sunan Ampel Malang 1994

Husain, Omar Amir, Kultur Islam, Bulan Bintang Jakarta 1979.

Ibn Taimiyah, Taqiyuddin Muhammad, Al Siyasat al Syar'iyat Fi Ishlah al Ra'I Wa al Ra'iyat, Dar al Jail Beirut 1988

Imam Abu Zakaria Yahya bin Sharf, Riyadhus Shalihin, al Ma'arif Bandung 1987

Kartoprawiro, Rusadi, Sistem Politik Indonesia, Sinar Baru Bandung 1986

Kunto Wijoyo, Dinamika Sejarah Umat Islam di Indonesia, Pustaka Pelajar Bandung 1994. . Paradikma Islam, Mizan Bandung 1992. . Budaya dan Masyarakat, Tiara Wacana, Yogyakarta 1986

Leach, Edmund, Dasar-dasar Teori Strukturalisme, dalam Adam Pargorecki, Pendekatan Sosiologis Terhadap Hukum, Terj. Bina Aksara 1987

Luwis, Abi Ma'luf, AlMunjid Fi al Lughah Wa al I'lam, Dar al Masyriq Beirut 1968.

Lyod, Cristhoper, Teori Sosial dan Praktek Politik, Terj. Rajawali Press Jakarta 1987.

Madjid, Noercholish, Islam Dotrin dan Peradapan, Yayasan Paramadina, Jakarta 1992. . Islam Agama Kemanusiaan, Yayasan Paramadina 1995

Millis, Matthew B. dan Huberman, A. Michael, 1992, Analisis Data Kualitatif, diterjemah oleh : Tjetjep Rohendi Rohidi, UI, Jakarta.

Moleong, Lexy, J., 1996, Metodologi Penelitian Kualitatif, Bandung, Remaja Rosdakarya Offset, Bandung.

Muhadjir, Noeng, 1996, Metode Penelitian Kualitatif, Rake Sarasih, Yogyakarta. 
Nasikun, Sistem Sosial di Indonesia, Rajawali Press Jakarta 1993

Nasution, S, 1998, Metode Penelitian Naturalistik Kualitatif, Persito Indonesia, Bandung.

Nothingham, Elizabeth K., Agama dan Masyarakat, Terj. Rajawali Press Jakarta 1996.

Pargorecki, Adam, Pendekatan Sosiologi Terhadap Hukum, Terj. Bina Aksara Bandung 1987.

Poewodarminto, WJS. Konus Besar Bahasa Indonesia, Balai Pustaka Jakarta 1980

Polama, Margareth M, Sosiologi Kontemporer, Terj. Rajawali Press Jakarta 1986.

Rakhmat, Djalaluddin, Skisme Dalam Sejarah Islam: Sebuah Telaah Dalam Budhi Munawar Rahman, Kontekrualisasi Dalom Doktrin Sejarah Islam, Paramadina Jakarta 1992.

. Ukhuwah Islamiyah: Perspektif Sejarah dan Al Qur'an, Mizan Bandung 1992.

Ritzer, George, Sosiologi Berparadikma Ganda, Terj. Rajawali Press Jakarta 1986.

Susanto, Astrid S, Pengantar sosiologi dan Perubahan Sosial, Bina Aksara Bandung 1993.

Svalastoga, Raare, Deferensiasi Sosial, Bina Cipta Bandung 1989.

Syalaby, A. Sejarah dan Kebudayaan Islam I dan II, Terj. Pustaka al Husna Jakarta 1990.

Syarwandi, Menara Kudus: Dalam Tinjauan Sejarah dan Arsitektur, Bulan Bintang Jakarta 1989.

Toneko, Soleman B, Struktur don Proses Sosial, Rajawali Press Jakarta 1980 Vieger, Kj. Realicas Sosial, Terj. Rajawali Press Jakarta 1986.

Wiratmo, JB Baruna SJ, Beberapa Pokok Tentang Masalah Berteologi Dewasa Ini, di alam Teologi dan Praktis Komunitas Post Modem, Kanisius Yogyakarta 1994.

Yasin, A.Fatah, Masjid Dalam Perspektif Pendidikan Islam, UMM Thesis 1999. 